\title{
FAKTOR FAKTOR YANG MEMPENGARUHI PERILAKU IBU DALAMMELAKUKAN DETEKSI DINI KANKER SERVIK DI DESA CIKUNIR KECAMATAN SINGAPARNA KABUPATEN TASIKMALAYA TAHUN 2013
}

Oleh:

Widya Maya Ningrum, S.ST, M.Kes

\begin{abstract}
A. Abstrak
Kanker serviks adalah tumbuhnya sel-sel abnormal pada serviks yang terjadi pada suatu daerah pada organ reproduksi wanita yang merupakan pintu liang senggama (vagina). Dan diantara banyak faktor yang mempengaruhi kesadaran ibu untuk melakukan deteksi dini terhadap kanker servik, diantarany adalah faktor predisposisi yang meliputi pengetahuan, sikap, keyakinan, kepercayaan, nilai, dan tradisi; faktor pemungkin adalah faktor yang memungkinkan atau yang memfasilitasi perilaku atau tindakan, yang meliputi sarana dan prasarana atau fasilitas untuk terjadinya perilaku yang terwujud dalam lingkungan fisik; dan selanjutnya adalah faktor pendorong, yaitu faktor-faktor yang mendorong atau memperkuat terjadinya perilaku. Berdasarkan laporan puskesmas Desa Cikunir tahun 2013, tercatat jumlah wanita usia subur 1.547 orang. Dan berdasarkan laporan dari Puskesmas Singaparna belum ada yang tercatat pernah melakukan deteksi kanker servik dengan melakukan IVA test atau pap' smear. Hal ini menunjukan masih kurang pedulinya wanita melakukan pemeriksaan deteksi dini padahal sangat rentan untuk menderita kanker servik.

Penelitian ini bertujuan untuk mengetahui faktor yang mempengaruhi perilaku ibu dalam melakukan deteksi dini kanker servik di Desa cikunir Kecamatan Singaparna Kabupaten Tasikmalaya tahun 2013 Penelitian ini merupakan jenis kuantitatif dengan metode deskriptif, yang bertujuan untuk mengambarkan faktor yang mempengaruhi perilaku wanita dalam melakukan deteksi dini kanker serviks.

Pengumpulan data dilakukan oleh peneliti dengan terlebih dahulu mempersiapkan berbagai format yang dibutuhkan sebagai instrumen guna memudahkan pengumpulan data. Pengumpulan data dalam penelitian ini adalah data primer, dimana data langsung didapatkan dari responden melalui intrumen yang dibagikan dan diisi langsung oleh responden, Pengumpulan data sekunder sebagai data pendukung dilakukan dengan cara melakukan telaah dokumen yang sesuai dengan substansi dan kebutuhan penelitian.

Hasil penelitian ini dapat disimpulkan bahwa pengetahuan responden tentang deteksi dini kanker serviks sebagian besar kategori cukup sehingga hal ini sangat relevan dengan sikap yang ditunjukan oleh responden, dimana hasilnya sebagaian besar menunjukan sikap negatif. Ketika pengetahuan cukup dan sikap negatif perilaku yang muncul dari responden adalah sebagian besar tidak melakukan deteksi dini kanker serviks.
\end{abstract}

Kata Kunci: Perilaku Ibu, Deteksi Dini Kanker Serviks, Kanker Serviks 


\section{B. Latar Belakang}

Kanker serviks adalah salah satu penyakit kanker yang paling banyak terjadi pada kaum wanita. Fakta menunjukkan bahwa jutaan wanita di dunia terinfeksi virus HPV, yang dianggap penyakit lewat hubungan seksual yang paling umum di dunia (Tilong, 2012). Kanker serviks menduduki urutan tertinggi di Negara berkembang dan urutan ke-10 di Negara maju atau urutan ke 5 secara global (Nuranna, 2010)

Dari data Badan Kesehatan Dunia (WHO), diketahui terdapat 493.243 jiwa per tahun penderita kanker serviks baru di dunia, dengan angka kematian karena kanker ini sebanyak 273.505 jiwa per tahun (Emilia, 2010). Di Indonesia, ditemukan 15.000 kasus kanker serviks dan 8.000 pasien diantara nya meninggal (Yayasan Kanker Indonesia). Di Tasikmalaya di temukan kasus kanker serviks disebabkan oleh infeksi virus HPV (Human Pappiloma Virus) yang tidak sembuh dalam waktu yang lama. Jika kekebalan tubuh berkurang, maka infeksi ini bisa mengganas dan menyebabkan terjadinya kanker serviks. Kanker serviks akan sangat berbahaya jika sudah memasuki stadium lanjut.

Kanker serviks dapat disembuhkan jika dideteksi dan ditanggulangi sejak dini. Beberapa metode deteksi dini antara lain metode Pap Smear, IVA (Inspeksi Visual dengan Asam asetat), Thin Prep, dan Kolposkopi, vikografi, papnet (komputerisasi) (Nugroho,
2010). Cara yang paling mudah dan sangat efektif untuk melakukan deteksi dini adalah Pap Smear dan tes IVA. Pap smear adalah pengambilan sampel / contoh sel-sel serviks atau leher rahim yang kemudian dianalisa di laboratorium dengan mikroskopis. Hasil tes akan menunjukkan apakah ada infeksi atau radang serta sel-sel abnormal akan terlihat, sedangkan IVA tes adalah pemeriksaan skrining kanker serviks dengan cara melakukan pulasan asam asetat 3-5\% pada serviks. Jika menimbulkan bercak putih pada lesi prakanker maka wanita tersebut positif terkena kanker serviks.

\section{Metode \\ Ruang Lingkup Penelitian}

1. Metode

Penelitian jenis kuantitatif dengan metode deskriptif, yang bertujuan untuk mengambarkan faktor yang mempengaruhi perilaku wanita dalam melakukan deteksi dini kanker serviks.

\section{Populasi dan Sampel}

a. Populasi

Populasi dalam penelitian ini adalah seluruh wanita usia subur yang sudah menikah dengan jumlah 1.337 orang di Desa Cikunir Kecamatan Singaparna Kabupaten Tasikmalaya. b. Sampel

Pegambilan sampel dalam penelitian ini dilakukan dengan menggunakan teknik simple random sampling, dimana dari setiap sampel mempunyai kesempatan yang sama untuk terpilih menjadi responden dengan cara diacak 


\section{Instrumen dan Cara Pengumpulan Data}

\section{Instrumen Penelitian}

Instrumen utama dalam penelitian ini menggunakan kuesioner.

2. Cara Pengumpulan data.

Pengumpulan data dilakukan oleh peneliti dengan terlebih dahulu mempersiapkan berbagai format yang dibutuhkan sebagai instrumen guna yang sesuai dengan substansi dan kebutuhan penelitian.

\section{Hasil Penelitian}

Karakteristik Responden

1. Umur

Tabel 4.3 Distribusi Responden Berdasarkan Umur di Desa Cikunir Tahun 2013

\begin{tabular}{|c|c|c|c|c|c|c|}
\hline No & Variabel & Mean & Median & Standart Deviasi & Minimum & Maximum \\
\hline 1 & Umur & 31.75 & 32 & 7.317 & 18 & 47 \\
\hline
\end{tabular}

Tabel 4.3 menunjukkan bahwa rata-rata umur responden adalah 31.75 tahun, minimal umur 18 tahun, dan maksimal berumur 47 tahun.

2. Usia Menikah

Tabel 4.4 Distribusi Responden Berdasarkan Usia Saat Menikah di Desa Cikunir Tahun 2013

\begin{tabular}{|c|c|c|c|c|c|c|}
\hline No & Variabel & Mean & Median & Standart Deviasi & Maximum & Minimum \\
\hline 1 & Usia Menikah & 23.12 & 23 & 3.076 & 30 & 17 \\
\hline
\end{tabular}

Tabel 4.4 menunjukkan bahwa rata-rata usia saat menikah respoden adalah 23.12 tahun, minimal umur 17 tahun,dan maksimal berumur 30 tahun. memudahkan pengumpulan data. Pengumpulan data dalam penelitian langsung didapatkan dari responden melalui intrumen yang dibagikan dan diisi langsung oleh responden, Pengumpulan data sekunder sebagai data pendukung dilakukan dengan cara melakukan telaah dokumen. ini adalah data primer, dimana data 
a. Pengetahuan

Tabel 4.5 Distribusi Frekuensi Pengetahuan Responden di Desa Cikunir Tahun 2013

\begin{tabular}{|l|c|c|}
\hline \multicolumn{1}{|c|}{ Pengetahuan } & Jumlah & Persentasi \\
\hline Baik & 68 & 17 \\
\hline Cukup & 140 & 35.1 \\
\hline Kurang & 191 & 47.9 \\
\hline Jumlah & 399 & 100 \\
\hline
\end{tabular}

Tabel 4.5 menunjukkan bahwa pengetahuan responden paling banyak termasuk kategori kurang 191 orang $(47,9 \%)$, dan pengetahuan wanita yang termasuk kategori baik 68 orang $(17 \%)$.

c. Sikap

Tabel 4.6 Distribusi Frekuensi Sikap Responden di Desa Cikunir Tahun 2013

\begin{tabular}{|c|c|c|}
\hline Sikap & Jumlah & Presentasi \\
\hline Positif & 144 & $\mathbf{3 6 . 0 9}$ \\
\hline Negatif & 255 & $\mathbf{6 3 . 9 1}$ \\
\hline Jumlah & 399 & $\mathbf{1 0 0}$ \\
\hline
\end{tabular}

Tabel 4.6 menunjukkan bahwa sikap responden paling banyak termasuk kategori negatif 285 orang $(71,43 \%)$.

d. Perilaku Deteksi Dini

Tabel 4.7 Distribusi Frekuensi Perilaku Deteksi Dini Pada Responden di Desa Cikunir Tahun 2013

\begin{tabular}{|l|c|c|}
\hline \multicolumn{1}{|c|}{ Perilaku Deteksi Dini } & Jumlah & Persentasi \\
\hline Ya & 193 & 48.4 \\
\hline Tidak & 206 & 51.6 \\
\hline Jumlah & 399 & 100 \\
\hline
\end{tabular}

Tabel 4.7 menunjukkan bahwa perilaku e. Tabel silang pengetahuan ibu deteksi dini responden paling banyak dengan perilaku deteksi dini adalah tidak melakukan deteksi dini kanker serviks sebanyak 206 orang $(51,6 \%)$, dan yang melakukan deteksi dini kanker serviks sebanyak 193 $(48.4 \%)$.

Tabel 4.8 Pengetahuan Wanita usia subur mengenai Kanker Serviks Dengan Perilaku Deteksi Dini Kanker Serviks Di Desa Cikunir Tahun 2013 


\begin{tabular}{|l|c|c|c|c|c|c|}
\hline \multirow{3}{*}{ Pengetahuan } & \multicolumn{4}{|c|}{ Perilaku Deteksi dini } & \multicolumn{2}{c|}{ Total } \\
\cline { 2 - 6 } & \multicolumn{3}{|c|}{ Ya } & \multicolumn{2}{c|}{ Tidak } & \multicolumn{1}{c|}{} \\
\cline { 2 - 6 } & F & $\%$ & F & $\%$ & F & $\%$ \\
\hline Baik & $\mathbf{5 2}$ & $\mathbf{2 6 , 9 4}$ & $\mathbf{1 6}$ & $\mathbf{7 , 7 7}$ & $\mathbf{6 8}$ & $\mathbf{1 7 , 0 4}$ \\
\hline Cukup & $\mathbf{7 3}$ & $\mathbf{3 7 , 8 2}$ & $\mathbf{6 7}$ & $\mathbf{3 2 , 5 3}$ & $\mathbf{1 4 0}$ & $\mathbf{3 5 , 0 8}$ \\
\hline Kurang & $\mathbf{6 8}$ & $\mathbf{3 5 , 2 3}$ & $\mathbf{1 2 3}$ & $\mathbf{5 9 , 7 1}$ & $\mathbf{1 9 1}$ & $\mathbf{4 7 , 8 6}$ \\
\hline Jumlah & $\mathbf{1 9 3}$ & $\mathbf{1 0 0}$ & $\mathbf{2 0 6}$ & $\mathbf{1 0 0}$ & $\mathbf{3 9 9}$ & $\mathbf{1 0 0}$ \\
\hline
\end{tabular}

Berdasarkan tabel 4.8 menunjukkan bahwa yang paling banyak melakukan deteksi dini kanker serviks adalah pada pengetahuan wanita yang termasuk kategori cukup, yaitu sebanyak 73 orang atau $37,82 \%$ dan wanita yang paling banyak tidak melakukan deteksi dini kanker serviks yaitu pada pengetahuan wanita yang termasuk kategori kurang sebanyak 123 orang atau $59,71 \%$.

f. Tabel silang sikap dengan perilaku deteksi dini kanker serviks

Tabel 4.9 Sikap Wanita usia subur mengenai Kanker Serviks Dengan Perilaku Deteksi Dini Kanker Serviks Di Desa Cikunir Tahun 2013

\begin{tabular}{|c|c|c|c|c|c|c|}
\hline \multirow{2}{*}{ Sikap } & \multicolumn{4}{|c|}{ Perilaku deteksi Dini } & \multicolumn{2}{c|}{ Total } \\
\cline { 2 - 6 } & \multicolumn{2}{|c|}{ Ya } & \multicolumn{2}{c|}{ Tidak } & \multicolumn{2}{c|}{} \\
\cline { 2 - 7 } & F & $\%$ & F & \% & Jml & $\%$ \\
\hline Positif & $\mathbf{1 0 0}$ & $\mathbf{5 1 , 8 1}$ & $\mathbf{4 4}$ & $\mathbf{2 1 , 3 6}$ & $\mathbf{1 4 4}$ & $\mathbf{3 6 , 0 9}$ \\
\hline Negatif & $\mathbf{9 3}$ & $\mathbf{4 8 , 1 9}$ & $\mathbf{1 6 2}$ & $\mathbf{7 8 , 6 4}$ & $\mathbf{2 5 5}$ & $\mathbf{6 3 , 9 1}$ \\
\hline Jumlah & $\mathbf{1 9 3}$ & $\mathbf{1 0 0}$ & $\mathbf{2 0 6}$ & $\mathbf{1 0 0}$ & $\mathbf{3 9 9}$ & $\mathbf{1 0 0}$ \\
\hline
\end{tabular}

Berdasarkan tabel 4.9 menunjukkan bahwa yang paling banyak melakukan deteksi dini kanker serviks adalah pada sikap wanita yang termasuk kategori positif, yaitu sebanyak 100 orang atau $51,81 \%$ dan wanita yang

\section{E. Pembahasan}

Dari hasil penelitian diperoleh 191 responden berpengetahuan kurang yang tidak melakukan deteksi dini sebanyak 123 orang $(59,71 \%)$ dan dari 68 orang berpengetahuan baik , 52 orang responden $(26,94 \%)$ melakukan deteksi dini .dan dari 144 responden yang mempunyai sikap positif sebanyak 100 orang $(51,81 \%)$ melakukan deteksi dini kanker serviks, dan dari 255 orang yang mempunyai sikap negatif sebanyak paling banyak tidak melakukan deteksi dini kanker serviks yaitu pada sikap wanita yang termasuk kategori negatif sebanyak 162 orang atau $78,64 \%$.

162 orang $(78,64 \%)$ tidak melakukan deteksi dini kanker serviks.

Data tersebut menunjukkan bahwa perilaku deteksi dini dapat didasarkan oleh pengetahuan, dengan mendapatkan informasi yang cukup tentang deteksi dini kanker serviks maka akan banyak wanita yang bersedia melakukan deteksi dini kanker serviks. Tetapi tidak sedikit wanita yang berpengetahuan kurang yang melakukan deteksi dini kanker serviks dan ada juga wanita yang 
berpengetahuan baik tidak melakukan deteksi dini kanker serviks. Hal ini tergantung pada kesadaran masingmasing untuk melakukan deteksi dini kanker serviks. Pengetahuan yang baik tidak selalu berdampak baik, dan pengetahuan kurang tidak selalu berdampak buruk.

Berdasarkan uraian diatas dapat diindikasikan bahwa pengetahuan yang dimiliki responden berdampak terhadap perilaku wanita dalam melakukan deteksi dini. Perilaku deteksi dini dipengaruhi oleh pengetahuan dan sikap. Hal ini sependapat dengan teori Notoatmodjo (2001) pengetahuan dan sikap yang dimiliki oleh seseorang akan membentuk perilaku terhadap lingkungannya. Akan tetapi seseorang yang berpengetahuan baik dan bersikap positif tidak selamanya akan berdampak pada perilaku yang baik pula. Pengetahuan dan sikap tersebut bisa berasal dari sumber-sumber lain, tidak hanya melalui penyuluhan namun dapat pula dari media cetak dan elektronik atau bahkan pengalaman pribadi.. Pengetahuan dan sikap yang dimiliki responden mengenai kanker serviks ini akan membentuk perilaku deteksi dini kanker serviks.

Budaya dan adat ketimuran di Indonesia telah membentuk sikap dan persepsi yang jadi penghalang bagi perempuan untuk membuka diri kepada profesional medis dan mampu melindungi kesehatan reproduksinya. Akibatnya, kebanyakan pasien datang sudah pada stadium lanjut, hingga sulit diobati. Menurut penelitian bahwa sikap sangat berpengaruh terhadap prilaku wanita usia subur dalam melakukan deteksi dini kanker serviks. Wanita menolak dilakukan pap smear karena rasa malu dan tidak diizinkan olehsuami. Hal ini menunjukkan bahwa wanita enggan melakukan pemeriksaan pap smear karena itu merupakan suatu hal yang sangat tabu dan harus mendapat persetujuandari keluarga (suami) terlebih dahulu. Kuatnya tradisi dalam keluarga memengaruhi pemanfaatan pelayanan kesehatan. Kendala sosial masyarakat berkaitan dengan konsep tabu. Seperti kita ketahui kanker serviks merupakan kanker yang menyerang bagian sensitif dan tertutup perempuan. Bukan hal yang mudah untuk mendorong perempuan membuka diri dan mengizinkan pemeriksaan dilakukan oleh dokter atau paramedis laki-laki. Bagi masyarakat dengan pengetahuan yang cukup, maka tidak akan menjadi masalah, tapi bagaimana dengan masyarakat pedesaan bahkan pedalaman yang tingkat pengetahuannya masih kurang. Selain itu aspek kepercayaan masyarakat terhadap dokter dan paramedis masih belum merata.

Berbagai faktor yang dapat mempengaruhi pengetahuan dan sikap dari perilaku deteksi dini kanker serviks diantaranya adalah kurangnya informasi dari tenaga kesehatan, informasi dari media cetak maupun elektronik seperti $\mathrm{TV}$, radio, surat kabar, maupun majalah sehingga dalam hal ini responden kurang mendapati informasi mengenai kanker serviks yang akhirnya responden cenderung tidak melakukan deteksi dini kanker serviks. Pengetahuan akan membentuk sikap dan perilaku. Pengetahuandan sikap masyarakat tersebut dipengaruhi oleh sosial, budaya, dan ekonomi yang pada 
hakikatnya merupakan interaksi dari pengaruh lingkungan yang bersifat alami atau buatan, oleh karena itu tenaga kesehatan harus memberi pengetahuan yang bersifat positif kepada masyarakat. Ukuran keberhasilan penyuluhan adalah adanya perubahan dari negatif menjadi positif (Wiryo, 2001).

Peningkatan pengetahuan dan sikap tidak selalu menyebabkan terjadinya suatu perubahan akan tetapi ada hubungan yang positif yang berkaitan dengan perubahan tindakan. Tindakan tersebut mungkin tidak dapat berubah secara langsung sebagai respon terhadap kesadaran ataupun pengetahuan tapi efek kumulatif dari peningkatan kesadaran, pengetahuan berkaitan dengan nilai,

\section{F. Simpulan dan Saran}

\section{Simpulan}

Dari hasil penelitian dapat disimpulkan bahwa pengetahuan responden tentang deteksi dini kanker serviks sebagian besar kategori cukup sehingga hal ini sangat relevan dengan sikap yang

\section{Saran}

1. Bagi responden (WUS)

Meningkatkan pengetahuan dan sikap dapat dilakukan dengan berbagai cara, responden dapat melakukannya dengan cara mengunjungi pelayanan kesehatan (Puskesmas atau Bidan) untuk mendapatkan lebih banyak informasi tentang pentingnya deteksi dini kanker serviks.

2. Puskesmas

Memperbaiki sistem repoting recording, karena pada saat melakukan data pendahuluan catatan tentang pemeriksaan IVA test atau keyakinan, kepercayaan, minat dalam bertindak.

Berdasarkan uraian diatas, pengetahuan dan sikap yang dimiliki oleh responden menunjukkan bahwa pengetahuan dan sikap dapat mempengaruhi persepsi terhadap perilaku deteksi dini kanker serviks.Dengan demikian dapat dikatakan semakin tinggi pengetahuan dan semakin positif sikap yang ditimbulkan maka akan semakin baik pula persepsi terhadap perilaku deteksi dini. Akan tetapi tidak selamanya orang yang memiliki persepsi baik akan melalukan deteksi dini, dan tidak selamanya orang yang memiliki persepsi buruk tidak akan melakukan deteksi dini kanker servik

ditunjukan oleh responden, dimana hasilnya sebagaian besar menunjukan sikap negatif. Ketika pengetahuan cukup dan sikap negatif perilaku yang muncul dari responden adalah sebagian besar tidak melakukan deteksi dini kanker serviks.

Papsmear tidak terdokumentasi dengan baik, sehingga masyarakat yang telah melaukan deteksi dini tersebut tidak tercatat dengan baik.

Lebih meningkatkan sosialisiasi kepada masayarat tentang pentingnya deteksi dini kanker serviks, dengan memanfaatkan kegiatan kemasyarakatan yang ada.

Lebih banyak memberikan pelayanan masal dan gratis kepada masyarakat, sehingga bagi masyarakat yang tidak mampu, tetap akan mendapatkan kesempatan untuk melakukan deteksi dini kanker serviks 


\section{G. Referensi}

Affandi, 2007. Makalah Rangkuman Seminar Sehari Peningkatan Kesehatan Ibu hamil, bersalin, dan perinatal. http://ksuheimi.blogspot.com

Dinas Kesehatan. 2007. Profil Dinas

Kesehatan Kabupaten

Tasikmalaya.

Dinas Kesehatan. 2008. Profil Dinas

Kesehatan Kabupaten

Tasikmalaya.

Dinas Kesehatan. 2009. Profil Dinas

Kesehatan

Kabupaten

Tasikmalaya.

Dinas Kesehatan. 2010. Profil Dinas

Kesehatan

Kabupaten

Tasikmalaya.

Masinambow,E.K.M.1996

Metodologi dalam Penelitian

Kebudayaan. Oktober.

Jakarta: Pascasarjana UI. (paper).

Royston,E. 1994. Pencegahan

Kematian Ibu

Hamil.Perinasia, Jakarta

Suparmanto,2007. Penyebab

Kematian Ibu,

http://creasoft.wordpress.com

diakses tahun 2009
Varneys. 2004, Ilmu Kebidanan Varneys Midewifery Edisi ke 3.Bandung.

Winjosastro S. 2002, Ilmu Kebidanan. Edisi ke 3. Yayasan Bina Pustaka Sarwono Prawirohardjo. Jakarta.

WHO, Depkes RI \& FKM UI. 1999. Modul Safe Motherhood, Jakarta

Creswell,JohnW.1994. Research Design: Qualitative \& Quantitative Approaches. USA: SAGE Publication, Inc.

Miles, Matthew B dan Huberman, A. Michael 1992 Analisis Data Kualitatif. Terjemahan Tjetjep Rohendi Rohidi. Jakarta: UI Press. 